\title{
PELANGGARAN ADMINISTRASI DALAM PEMILIHAN GUBERNUR DAN WAKIL GUBERNUR, BUPATI DAN WAKIL BUPATI, SERTA WALIKDTA DAN WAKIL WALIKDTA TAHUN ZП2О
}

\author{
Budiman N.P.D Sinaga', Jahnson Pasaribu², Jherry Napitupulu \\ Magister Ilmu Administrasi Universitas HKBP Nommensen, Medan \\ budiman.sinaga国uhn.ac.id
}

Info Artikel
Diterima : 10 April 202।
Revisi : Z8 Mei 202।
Terbit : 28 Juni 202।

\section{Key words:}

Administrative, constitution, election.

\section{Kata Kunci:}

Administrasi, konstitusi, pemilihan

\section{Corresponding Author:}

Budiman N.P.D Sinaga,

Email:

budiman.sinaga国uhn.ac.id

\begin{abstract}
In the Constitution of the Republic of Indonesia 1945 it was stated that the election of regional heads was conducted democratically. As the implementation of the provision has been applied various laws and regulations but until now there are still various problems. Therefore, it is necessary to conduct research on the problems in the regional head election. Research was conducted on legislation and decisions. Based on the research can be known that in the Regional Head Election found also administrative violations. In resolving administrative violations, the role of administrative science is very important especially regarding evidence and evidence. Therefore, election organizers need to be equipped with administrative capabilities in order to prevent and resolve violations appropriately.
\end{abstract}

\section{Abstrak}

Dalam Undang-Undang Dasar Negara Republik Indonesia 1945 dinyatakan bahwa Pemilihan Kepala Daerah dilakukan secara demokratis. Sebagai pelaksanaan ketentuan itu telah diberlakukan berbagai peraturan perundang-undangan tetapi sampai sekarang masih muncul berbagai masalah. Dleh karena itu perlu dilakukan penelitian mengenai permasalahan dalam Pemilihan Kepala Daerah. Penelitian dilakukan terhadap peraturan perundang-undangan dan putusan. Berdasarkan penelitian dapat diketahui bahwa dalam Pemilihan Kepala Daerah ditemukan juga pelanggaran administrasi. Dalam penyelesaian pelanggaran administrasi maka peran ilmu administrasi sangat penting terutama menyangkut alat bukti dan barang bukti. Cleh karena itu, para pelaksana pemilihan perlu dilengkapi dengan kemampuan administrasi agar dapat mencegah dan menyelesaikan pelanggaran dengan tepat. 


\section{PENDAHULLAN}

Dalam Pasal I8 Undang-Undang Dasar Negara Republik Indonesia Tahun 1945 (UUD 1945) ditentukan sebagai berikut:

(I) Negara Kesatuan Republik Indonesia dibagi atas daerah-daerah provinsi dan daerah provinsi itu dibagi atas kabupaten dan kota, yang tiap-tiap provinsi, kabupaten, dan kota itu mempunyai pemerintahan daerah yang diatur dengan undang-undang.

(2) Pemerintahan daerah provinsi, daerah kabupaten, dan kota mengatur dan mengurus sendiri urusan pemerintahan menurut asas otonomi dan tugas pembantuan.

(3) Pemerintahan daerah provinsi, daerah kabupaten, dan kota memiliki Dewan Perwakilan Rakyat Daerah yang anggota-anggotanya dipilih melalui pemilihan umum.

(4) Gubernur, Bupati, dan Walikota masingmasing sebagai kepala pemerintah daerah provinsi, kabupaten, dan kota dipilih secara demokratis.

(5) Pemerintahan daerah menjalankan otonomi seluasluasnya, kecuali urusan pemerintahan yang oleh undangundang ditentukan sebagai urusan Pemerintah Pusat.

(G) Pemerintahan daerah berhak menetapkan peraturan daerah dan peraturan-peraturan lain untuk melaksanakan otonomi dan tugas pembantuan.

(7) Susunan dan tata cara penyelenggaraan pemerintahan daerah diatur dalam undang-undang.

Dalam ketentuan Pasal 18 ayat (4) UUD IS45 di atas disebutkan bahwa Gubernur, Bupati, dan Waliknta masing-masing sebagai kepala pemerintah daerah provinsi, kabupaten, dan kota dipilih secara demakratis. Perhatikan pemakaian ungkapan "pemerintah daerah". Pemerintah daerah (tanpa akhiran "an"), dimaksudkan sebagai pemegang atau yang menjalankan kekuasaan eksekutif yaitu kepala daerah dan jajarannya.' Kata-kata lain yang perlu diperhatikan adalah "secara demokratis". Kata-kata "secara demokratis" tidak harus berarti melalui pemilihan langsung oleh rakyat atau pemilihan umum saja melainkan dapat juga melalui cara-cara lain termasuk pemilihan oleh Dewan Perwakilan Rakyat Daerah (DPRD). Cleh karena itu cara Pemilihan Kepala Daerah melalui pemilihan langsung yang berlaku sekarang dan cara Pemilihan Kepala Daerah melalui DPRD yang berlaku pada masa lalu dapat dikatakan tidak ada yang bertentangan dengan ketentuan UUD 1945.

Sejak beberapa tahun lalu sampai sekarang media massa hampir setiap hari memberitakan perilaku menyimpang dari Kepala Daerah ataupun anggota DPRD, entah dalam kasus money politic dalam Pemilihan Kepala Daerah, pembahasan laporan pertanggungjawaban, karupsi dana APBD, penjualan aset-aset Pemerintah Daerah, ataupun dalam kasus-kasus lain. ${ }^{2}$ Perilaku menyimpang dari Kepala Daerah dan anggota DPRD itu diduga berkaitan erat dengan Pemilihan Kepala Daerah yang dilakukan oleh DPRD. Kenyataan ini telah memunculkan pemikiran agar Kepala Daerah tidak dipilih oleh DPRD melainkan dipilih langsung oleh rakyat.

Berbagai upaya telah dilakukan untuk mengatasi berbagai penyimpangan di atas terutama berkaitan dengan Pemilihan Kepala Daerah, antara lain melalui perubahan peraturan perundang-undangan. Perubahan peraturan perundang-undangan tentang Pemilihan Kepala Daerah telah dilakukan berkali-kali bahkan dalam kurun waktu yang sangat singkat. Undang-Undang Nomar I Tahun 2015 tentang Penetapan Peraturan Pemerintah Pengganti Undang-Undang Nomar I Tahun 2014 tentang Pemilihan Gubernur, Bupati, dan

\footnotetext{
'Bagir Manan, Perkembangan UلDD 1945, Yogyakarta: FH UII Press, 2004, hal.38.

${ }^{2}$ Ni'matul Huda, Otonomi Daerah. Filosofi. Sejarah Perkembangannya, dan Prablematika, Yogyakarta: Pustaka Pelajar, 2005, hal. 187.
} 
Walikata menjadi Undang-Undang yang baru berlaku beberapa bulan telah diubah dengan Undang-Undang Nomar 8 tahun 2015 Tentang Perubahan atas Undang-Undang Nomor I Tahun 2015 Tentang Penetapan Peraturan Pemerintah Pengganti Undang-Undang Nomor I Tahun 2014 tentang Pemilihan Gubernur, Bupati, dan Walikata padahal Undang-Undang ini pun belum lama berlaku sebagai perubahan dari Undang-Undang Nomar 22 Tahun 2014 tentang Pemilihan Gubernur, Bupati, dan Walikota.

Dalam berbagai peraturan perundang-undangan mengenai Pemilihan Kepala Daerah telah dimuat berbagai sanksi yang dapat dijatuhkan kepada pihak-pihak atau orang yang melanggar terutama bagi peserta dan penyelenggaran pemilihan umum. Akan tetapi, pada kenyataannya berbagai sanksi termasuk sanksi pidana belum membuat berbagai pihak yang terlibat dalam Pemilihan Kepala Daerah menaati berbagai peraturan perundang-undangan yang mengatur Pemilihan Kepala Daerah. Tidak heran jika hampir pada setiap Pemilihan Kepala Daerah dapat ditemukan kasus-kasus hukum baik pidana, perdata, administrasi, maupun bidang hukum yang lain.

Mengenai Pemilihan Kepala Daerah sampai saat ini masih saja ada perdebatan mengenai, apakah Pemilihan Kepala Daerah termasuk pemilihan umum atau tidak? Perdebatan muncul karena ketentuan dalam UUD 1945 dipandang tidak tegas. Pasal 18 ayat (4) UUD 1945 berbunyi sebagai berikut: "Gubernur, Bupati, dan Walikota masing-masing sebagai kepala pemerintah daerah provinsi, kabupaten, dan kota dipilih secara demokratis." Kebanyakan berpendapat Pemilihan Kepala Daerah secara langsung itu lebih demokratis. Paling tidak ada dua alasan mengapa gagasan pemilihan langsung dianggap perlu. Pertama, untuk lebih membuka pintu bagi tampilnya Kepala Daerah yang sesuai dengan kehendak mayoritas rakyat sendiri. Kedua, untuk menjaga stabilitas pemerintahan agar tidak mudah dijatuhkan di tengah jalan. ${ }^{3}$ Akan tetapi permasalahan seputar Pemilihan Kepala Daerah ternyata masih saja ada walaupun telah dilakukan secara langsung bahkan lebih banyak daripada ketika dilakukan secera tidak langsung atau melalui DPRD.

Sehubungan dengan uraian di atas dipandang perlu untuk melakukan penelitian berkaitan dengan Pemilihan Kepala Daerah dengan judul "Pelanggaran Administrasi Pemilihan Gubernur dan Wakil Gubernur, Bupati dan Wakil Bupati, serta Walikata dan Wakil Walikata Tahun 2020." Adapun permasalahan yang hendak dijawab melalui penelitian ini adalah apakah yang dimaksud dengan pelanggaran administrasi dalam pemilihan Gubernur dan Wakil Gubernur, Bupati dan Wakil Bupati, serta Waliknta dan Wakil Waliknta Tahun 2020.

\section{METODE PENELITIAN}

\section{Tujuan penelitian}

Tujuan penelitian ini adalah untuk mengetahui dan memahami pelanggaran administrasi dalam Pemilihan Gubernur dan Wakil Gubernur, Bupati dan Wakil Bupati, serta Walikota dan Wakil Walikota Tahun 2020.

\section{Manfaat Penelitian}

Hasil penelitan ini diharapkan akan dapat dimanfaatkan secara teoritis maupun praktis. Secara teoritis hasil penelitian ini diharapkan akan memperkaya teori-teori yang sudah ada di bidang hukum dan administrasi mengenai pemilihan umum. Secara praktis hasil penelitian ini diharapkan akan dapat dimanfaatkan secara langsung untuk meningkatkan kualitas pelaksanaan pemilihan Gubernur dan Wakil Gubernur, Bupati dan Wakil Bupati, serta Waliknta dan Wakil Waliknta pada masa yang akan datang.

${ }^{3}$ lbid, hal. 204.

Pelanggaran Administrasi Pemilihan Gubernur dan Wakil Gubernur, Bupati dan Wakil Bupati, Serta Walikata dan Wakil Walikata Tahun 2020 


\section{Bahan Penelitian}

Bahan yang digunakan dalam penelitian ini mencakup bahan primer, sekumder, maupun tersier. Penelitian tidak hanya dilakukan terhadap peraturan perundang-undangan melainkan buku-buku dan bahan lain sepanjang berkaitan dengan pemilihan umum melalui pendekatan kasus dan Undang-Undang. Pendekatan kasus (case appraach) dilakukan dengan mengkaji kasus-kasus yang berkaitan dengan pemilihan umum. Sementara itu, pendekatan Undang-undang (statute appraah) dilakukan dengan mengkaji berbagai peraturan perundangundangan tentang pemihan umum. Bahan-bahan yang terkumpul kemudian dianalisis secara kualitatif dan kuantitatif.

\section{HASIL DAN PEMBAHASAN}

\section{Pemilihan Umum}

Pemilihan umum (Pemilu) merupakan kegiatan yang lazim dilaksanakan di negara-negara demakrasi untuk memilih orang-orang yang akan menduduki jabatan tertntu terutana lembaga perwakilan rakyat atau lembaga legislatif. Dalam perkembangannya Pemilu tidak hanya dalam rangka memilih anggata lembaga legislatif melainkan lembaga eksekutif juga. Padahal semula Pemilu hanya untuk memilih anggata legislatif kemudian mereka inilah yang akan memilih orang-orang yang akan menduduki jabatan di lembaga eksekutif.

Seiring dengan perkembangan negara maka Pemilu tidak hanya dalam rangka mengisi keanggataan lembaga legislatif dan eksekutif tingkat pusat melainkan daerah juga. Oleh karena itu, Pemilu tidak lagi hanya dilakukan secara nasional mencakup seluruh negara melainkan per wilayah atau daerah tertentu juga. Pelaksaan masing-masing pemilu itu dapat dilakukan secara bersama-sama atau serentak maupun berbeda-beda untuk setiap lembaga dan daerah.

Dalam rangka mengupayakan pelaksanaan pemilu yang baik diperlukan peraturan perundang-undangan. Pada umumnya ahli hukum sependapat bahwa peraturan hukum yang dinilai ideal dan perfect (sempurna) itu ialah jika memenuhi 3 (tiga) macam syarat sekaligus fungsi yang berikut ini:

1) Peraturan hukum itu memberi kepastian hukum (rechtszekerheid, law certainty, rechtsmassigkeit).

2) Peraturan hukum itu memberi keadilan (rechtszegerechtigheid, justice, rechtszerechtigheid).

3) Peraturan hukum itu mendatangkan kemandatan (utiliteig, utilitat, utility). ${ }^{4}$

Semua peraturan perundang-undangan dapat dikatakan telah diupayakan agar memenuhi syaratsyarat tersebut tetapi pada kenyataannya selalu saja masih mengandung kekurangan bahkan kesalahan. Dleh karena itu, dimungkinkan perubahan bahkan pergantian peraturan perundang-undangan supata lebih baik sehingga tidak menimbulkan masalah.

\section{Penyelesaian Sengketa Pemilihan Umum}

Pemilu sesungguhnya buka hanya berupa pemilihan atau bahkan pencoblosan suara melainkan serangkaian tahaoan kegiatan yang panjang, baik sebelum maupun setelah pencoblosan suara. Sepanjang tahapan itu terbuka kemungkinan terjadi sengketa atau terjadi sengketa Pemilu. Sengketa dapat terjadi antara peserta dengan penyelenggara pemilu maupun pihak-pihak lain yang terlibat dalam kegiatan Pemilu.

Secara umum peserta Pemilu adalah Partai Politik atau gabungan partai politik. Akan tetapi dalam beberapa Pemilu dimungkinkan juga selain Partai Politik sebagai peserta seperti golongan tertentu bahkan

${ }^{4}$ M Solly Lubis, Politik Hukum dan Kebijakan Publik (Legal Policy and Public Policy). Bandung: Mandar Maju, 2014, hal.24. 
perorangan. Pemlu yang diikuti peserta perarangan antara lain dalam pemilihan senat dan pemilihan Presiden yang dikenal sebagai calan independen. Kemungkinan calan perarangan ini kemudian diikuti juga dalam pemilihan lain termasuk Pemilihan Kepala Daerah.

Penyelesaian sengketa Pemilu dapat dilakukan oleh lembaga-lembaga penegak hukum yang sudah ada seperti Polisi, Jaksa, dan Hakim. Selain itu penyelesaian sengketa dapat dilakukan oleh lembaga-lembaga yang dapat dikategarikan sebagai lembaga penyelenggara Pemilu atau lembaga-lembaga penyelesaian sengketa yang khusus diadakan dalam rangka Pemilu.

Secara umum sengketa hukum mencakup bidang hukum pidana, perdata, dan tata usaha negara atau administrasi. Sengketa dalam Pemilu juga dapat dikatakan mencakup bidang hukum pidana, perdata, administrasi. Dalam hal ini suatu sengketa di bidang tertentu dapat saja berkaitan dengan bidang-bildang lain juga sehingga penyelesaian sengketa juga dilakukan secara bersama-sama atau berkelanjutan.

\section{Pemilihan Gubernur dan Wakil Gubernur, Bupati dan Wakil Bupati, serta Walikata dan Wakil Walikota}

Dalam UUD dapat ditemukan berbagai pasal yang berkaitan dengan Pemilu. Dalam Pasal Pasal I ayat (2) disebutkan bahwa Kedaulatan berada di tangan rakyat dan dilaksanakan menurut Undang-Undang Dasar. Dleh karena rakyat yang memegang kedaulatan maka kedaulatan itu harus diwujudkan dalam memilih orang-orang yang akan memegang jabatan-jabatan tertentu melalui Pemilihan Umum (Pemilu). Kemudian Pasal GA yang berbunyi:

(I) Presiden dan Wakil Presiden dipilih dalam satu pasangan secara langsung oleh rakyat.

(2) Pasangan calon Presiden dan Wakil Presiden diusulkan oleh partai politik atau gabungan partai politik peserta pemilihan umum sebelum pelaksanaan pemilihan umum.

(3) Pasangan calon Presiden dan Wakil Presiden yang mendapatkan suara lebih dari lima puluh persen dari jumlah suara dalam pemilihan umum dengan sedikitnya dua puluh persen suara di setiap provinsi yang tersebar di lebih dari setengah jumlah provinsi di Indonesia, dilantik menjadi Presiden dan Wakil Presiden.

(4) Dalam hal tidak ada pasangan calon Presiden dan Wakil Presiden terpilih, dua pasangan calan yang memperaleh suara terbanyak pertama dan kedua dalam pemilihan umum dipilih oleh rakyat secara langsung dan pasangan yang memperoleh suara rakyat terbanyak dilantik sebagai Presiden dan Wakil Presiden.

(5) Tata cara pelaksanaan pemilihan Presiden dan Wakil Presiden lebih lanjut diatur dalam undang-undang. Berdasarkan ketentuan di atas maka Presiden dan Wakil Presiden dipilih secara langsung oleh rakyat melalui Pemilu. Selanjutnya dalam Pasal ZZE disebutkan pula sebagai berikut:

(I) Pemilihan umum dilaksanakan secara langsung, umum, bebas, rahasia, jujur, dan adil setiap lima tahun sekali.

(2) Pemilihan umum diselenggarakan untuk memilih anggata Dewan Perwakilan Rakyat, Dewan Perwakilan Daerah, Presiden dan Wakil Presiden dan Dewan Perwakilan Rakyat Daerah.

(3) Peserta pemilihan umum untuk memilih anggata Dewan Perwakilan Rakyat dan anggata Dewan Perwakilan Rakyat Daerah adalah partai politik.

(4) Peserta pemilihan umum untuk memilih anggota Dewan Perwakilan Daerah adalah persearangan. 
(5) Pemilihan umum diselenggarakan oleh suatu komisi pemilihan umum yang bersifat nasional, tetap, dan mandiri.

(G) Ketentuan lebih lanjut tentang pemilihan umum diatur dengan undang-undang.

Menurut ketentuan di atas Pemilu dilaksanakan untuk memilih anggata Dewan Perwakilan Rakyat, Dewan Perwakilan Daerah, Presiden dan Wakil Presiden dan Dewan Perwakilan Rakyat Daerah. Kemudian Pasal 18 ayat (4) yang menyebutkan bahwa Gubernur, Bupati, dan Walikata masing-masing sebagai kepala pemerintah daerah provinsi, kabupaten, dan kata dipilih secara demakratis. Penggunaan istilah demokratis membuka kemungkinan dipilih secara langsung atau tidak langsung. Ketentuan ini berbeda dengan pemilihan Presiden dan Wakil Presiden yang secara tegas menghendaki pemilihan secara langsung. Peraturan perundang-undangan yang mengatur mengenai pemilihan Gubernur, Bupati, dan Walikata sudah mengalami perubahan berkali-kali.

Sementara itu dalam Pasal 24 ayat (I) disebutkan bahwa Mahkamah Konstitusi berwenang mengadili pada tingkat pertama dan terakhir yang putusannya bersifat final untuk menguji undang-undang terhadap Undang-Undang Dasar, memutus sengketa kewenangan lembaga negara yang kewenangannya diberikan oleh Undang-Undang Dasar, memutus pembubaran partai politik, dan memutus perselisihan tentang hasil pemilihan umum. Ketentuan ini berkaitan dengan Pemilu terutama mengenai pembubaran partai politik dan perselisihan hasil Pemilu.

\section{Penyelesaian Sengketa Pemilihan Gubernur dan Wakil Gubernur, Bupati dan Wakil Bupati, serta Walikota dan Wakil Waliknta}

Sebagaimana telah disampaikan peraturan perundang-undangan yang mengatur mengenai Pemilihan Gubernur dan Wakil Gubernur, Bupati dan Wakil Bupati, serta Walikata dan Wakil Walikata telah berulang kali dilakukan perubahan. Cleh karena itu, dapat ditemukan berbagai istilah berkaitan dengan Pemilihan Gubernur dan Wakil Gubernur, Bupati dan Wakil Bupati, serta Walikata dan Wakil Walikata, antara lain Pemilihan Kepala Daerah (Pilkada), pemilihan umum kepala daerah (pemilukada), atau Pemilihan Gubernur dan Wakil Gubernur. Bupati dan Wakil Bupati, serta Walikata dan Wakil Walikata. Dalam tulisan ini istilah-istilah itu masih digunakan terutama jika mengutip peraturan perundang-undangan atau pendapat.

Sehubungan dengan perubahan peraturan perundang-undangan itu maka dinamika perkembangan pembangunan hukum tentang pemilihan umum kepala/wakil kepala daerah di Indanesia, sangat dinamis, mengingat terjadinya perubahan ketentuan dimaksud dari waktu ke waktu, periode ke periode, berkembang sangat dinamis, mengikuti perkembangan zaman. ${ }^{5}$ Perubahan peraturan perundang-undangan seiring dengan perkembangan zaman memang tidak dilarang tetapi harus dilakukan secara berhati-hati karena dapat mengurangi bahkan menghilangkan kepastian hukum. Terbuka kemungkinan berdasarkan satu peraturan perundang-undangan sesearang dapat menjadi Gubernur tetapi setelah ada perubahan bisa saja dia menjadi tidak memenuhi syarat. Hal-hal semacam ini perlu dihindari agar nasib rakyat tidak terambang-ambing. Barangkali hal ini yang menyebabkan dalam beberapa kali pemilihan di beberapa daerah hanya ada satu pasangan. Padahal meskipun hanya ada satu pasangan calon dalam pilkada, proses pemungutan suara tetap

\footnotetext{
${ }_{5}^{5}$ Marulak Pardede, Legitimasi Pemilihan Kepala/Wakil Kepala Daerah Dalam Sistem Pemerintahan Dtanomi Daerah (Legitimacy of Regiona/ Head/Deputy Head Election in The Regiana/Autonomaus Administration System), Jurnal Penelitian Hukum DE JURE, ISSN I4ID-5632 Vol. I8 No. Z, Juni 2018: 145.
} 
merupakan hal yang harus dikerjakan karena hak pilih masyarakat merupakan kedaulatan rakyat yang keberadaannya dijamin oleh konstitusi. ${ }^{B}$ Adapun kerangka Hukum Pemilukada adalah ${ }^{7}$

I. Undang-Undang Dasar Negara Republik Indonesia Tahun 1945 khususnya Pasal 18, 22 E, dan Pasal 24С.

2. Undang-Undang Nomor 7 Tahun 2017 tentang Pemilihan Umum.

3. Undang-Undang Nomor I Tahun 2015 tentang Penetapan Peraturan Pemerintah Pengganti UndangUndang Nomar I Tahun 2014 tentang Pemilihan Gubernur, Bupati, dan Walikata jo Undang-Undang Nomar 8 Tahun 2015 tentang Perubahan Undang-Undang Nomor I Tahun 2015 jo Undang-Undang Nomor IO Tahun 2016 tentang Perubahan Kedua Undang-Undang Nomor I Tahun 2015 jo Peraturan Pemerintah Pengganti Undang-Undang Nomar 2 Tahun 2020 tentang Perubahan Ketiga UndangUndang Nomar I Tahun 2015.

4. Peraturan Komisi Pemilihan Umum.

5. Peraturan Badan Pengawas Pemilihan Umum.

6. Peraturan Dewan Kehormatan Penyelenggara Pemilihan Umum Republik Indonesia Nomor 2 Tahun 2017 tentang Kode Etik dan Pedaman Perilaku Penyelenggara Pemilihan Umum.

7. Peraturan Bersama Badan Pengawas Pemilihan Umum, Kepala Kepolisian Republik Indonesia, Kejaksaan Agung Nomar 5 Tahun 2020 tentang Sentra Penegakan Hukum Terpadu pada Pemilihan Gubernur dan Wakil Gubernur, Bupati dan Wakil Bupati, Walikota dan Wakil Walikota (Sentra GAKKLMDU).

8. Peraturan Mahkamah Kanstitusi Nomor 5 Tahun 2017 tentang Pedoman Beracara dalam Perkara Perselisihan Hasil Pemilihan Gubernur, Bupati, dan Waliknta.

9. Peraturan Mahkamah Konstitusi Nomar 6 Tahun 2017 tentang Pedoman Beracara dalam Perkara Perselisihan Hasil Pemilihan Gubernur, Bupati, dan Walikata dengan satu pasangan calon.

10. Peraturan Perundang-undangan terkait lainnya, antara lain Kitab Undang-Undang Hukum Pidana (KLHP), UU Aparatur Sipil Negara (ASN), UU TNI/PQLRI, UU Keterbukaan Infarmasi Publik (KIP), UU Infarmasi dan Transaksi Elektronik (ITE) dan peraturan perundang-undangan lainnya yang berkaitan maupun berurusan dengan pelaksanaan pemilu atau pemilukada.

Berdasarkan peraturan perundang-undangan di atas pelanggaran Pemilukada dapat dibedakan menjadi 3 (tiga) jenis, yaitu:

1. Pelanggaran Administrasi Pemilukada.

2. Tindak Pidana Pemilukada.

3. Pelanggaram Kode Etik Penyelenggara Pemilukada.

4. Pelanggaran peraturan perundang-undangan lainnya (di luar UU Pemilukada).

Selain 4 (empat) jenis pelanggaran Pemilukada di atas, dalam penegakan hukum Pemilukada juga dikenal istilah Sengketa Pemilihan. ${ }^{8}$

\footnotetext{
6 Wafia Silvi Dhesinta, Calon Tunggal Dalam Pemilihan Umum Kepala Daerah dan Konsep Demokrasi (Analisis Terhadap Pemilihan Kepala Daerah Kabupaten Blitar Tahun 2015), Jurnal Cita Hukum. Vol. 4 No. I Juni 20I6. P-ISSN: 2356-1440. E-ISSN: 250Z-23DX, hal.IDZ.

${ }^{7}$ Herdi Munte, Pengantar Pelanggaran dan Sengketa Hukum Pemilukada (Teari dan Praktek). Medan: Enam Media, 2020, hlm. ID-II.

${ }^{8}$ Herdi Munte, Pengantar Pelanggaran dan Sengketa Hukum Pemilukada (Teari dan Praktek). Medan: Enam Media, 2020, hlm. 50.
}

Pelanggaran Administrasi Pemilihan Gubernur dan Wakil Gubernur, Bupati dan Wakil Bupati, Serta Walikata dan Wakil Walikata Tahun 2020 
Pelanggaran administrasi adalah pelanggaran ketentuan, tata cara, prosedur, mekanisme yang diatur

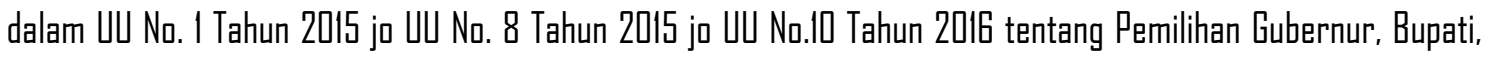
dan Waliknta maupun pelanggaran terhadap ketentuan lain yang diatur dalam Peraturan KPU terkait penyelenggaraan Pemilukada yang BUKAN merupakan ketentuan tindak pidana Pemilukada dan kade etik penyelenggara Pemilukada.

Pada peristiwa/pelanggaran hukum Pemilukada maka pihak yang melanggar disebut sebagai Terlapar. Dalam pelanggaran administrasi pihak yang diposisikan sebagai Terlapor adalah:

1) Penyelenggara Pemilu.

2) Pasangan calon.

3) Tim kampanye.

4) Masyarakat/Pemilih.

Pelanggaran administrasi terkait larangan memberikan dan/atau menjanjikan uang atau materi lainnya yang dilakukan secara Terstruktur, Sistematis, dan Masif (TSM). Dalam Pemilukada juga dikenal pelanggaran administrasi terkait larangan memberikan dan/atau menjanjikan uang atau materi lainnya yang dilakukan secara Terstruktur, Sistematis, dan Masif (TSM). Yang menjadi obyek pelanggaran administrasi ini adalah perbuatan menjanjikan dan/atau memberikan uang atau materi lainnya untuk mempengaruhi penyelenggara Pemilu dan/atau Pemilih yang terjadi secara Terstruktur, Sistematis, dan Masif (TSM).

Selanjutnya akan dikemukan beberapa hal yang diatura dalam Peraturan Badan Pengawas Pemilihan Umum (BAWASLU) Nomar 13 tahun 2017 tentang Tata Cara Penanganan Pelanggaran Administrasi Terkait Larangan Memberikan dan/atau Menjanjikan Uang atau Materi Lainnya Yang Dilakukan Secara Terstruktur. Sistematis, dan Masif Dalam Pemilihan Gubernur, Bupati, dan Waliknta.

Objek pelanggaran administrasi meliputi perbuatan menjanjikan dan/atau memberikan uang atau materi lainnya untuk mempengaruhi penyelenggara Pemilihan dan/atau Pemilih yang terjadi secara terstruktur, sistematis, dan masif. Terlapor dalam dugaan pelanggaran administrasi terdiri atas:

a. aparat pemerintah;

b. penyelenggara pemilihan;

c. Calon Gubernur dan/atau Calon Wakil Gubernur;

d. Calon Bupati dan/atau Calon Wakil Bupati;

e. Calon Wali Kotadan/atau Calon Wakil Wali Kota;

f. tim Kampanye;

g. relawan pasangan calon;

h. anggota partai politik;

i. . .ketua, wakil ketua, ketua muda, hakim agung pada Mahkamah Agung, dan hakim pada semua badan peradilan di bawah Mahkamah Agung, dan hakim konstitusi pada Mahkamah Konstitusi;

j. ketua, wakil ketua, dan anggota Badan Pemeriksa Keuangan;

k. gubernur, deputi gubernur senior, dan deputi gubernur Bank Indonesia;

I. direksi, komisaris, dewan pengawas dan karyawan badan usaha milik negaraatau badan usaha milik daerah;

m. pejabat negara bukan anggota partai politik yang menjabat sebagai pimpinan di lembaga nonstruktural; 
п. orangpersearangan; dan/atauo.badan hukum;

Sementara itu aparat pemerintah terdiri atas:

a. pegawai negeri sipil;

b. anggata Tentara Nasional Indanesia dan Kepolisian Negara Republik Indanesia;

c. pegawai pemerintah dengan perjanjian kerja;

d. kepala desa/lurah atau sebutan lainnya;

e. kepala dusun atau sebutan lainnya;

f. rukun tetangga atau rukun warga; dan/atau

g. pegawai pemerintah atau pejabat yang diangkat dalam rangka melaksanakan tugas pemerintahan serta dibiayai dengan keuangan negara.

Adapun Penyelenggara Pemilihan terdiri atas:

a. anggata KPU, KPU/KIPProvinsi/Aceh, KPU/KIP Kabupaten/Kata, Panitia Pemilihan Kecamatan, Panitia Pemungutan Suara, dan Kelompok Penyelenggara Pemungutan Suara,serta jajaran sekretariat KPU sesuai dengan tingkatannya;

b. anggata Bawaslu, Bawaslu Provinsi, Panwas Kabupaten/Kota, Panitia Pengawasan Pemilihan Kecamatan, Pengawas Pemilihan Lapangan, dan Pengawas Tempat Pemungutan Suara,serta jajaran sekretariat Pengawas Pemilihan sesuai dengan tingkatannya; dan

c. anggata dan sekretariat Dewan Kehormatan Penyelenggara Pemilihan Umum dan tim pemeriksa daerah.

Tim kampanye terdiri atas:

a. ketua dan angguta tim kampanye;

b. tim pemenangan, relawan pasangan calon, atau sebutan lain;

c. partai pengusung dan partai pendukung pasangan calon baik ditingkat pusat maupun ditingkat daerah; dan

d. organisasi sayap partai politik pengusung dan partai politik pendukung pasangan calon.

Relawan pasangan calon merupakan kelompok orang yang melakukan kegiatan/aktivitas untuk mendukung pasangan calon tertentu secara sukarela dalam Pemilihan. Orang persearangan merupakan arang perarangan yang terlibat dalam kegiatan Pemilihan. Badan hukum merupakan badan hukum yang terlibat dalam kegiatan Pemilihan meliputi:

I. badan usaha milik negara/daerah;

2. perseroan terbatas;

3. yayasan; dan

4. koperasi, yang didirikan sesuai dengan ketentuan peraturan perundang-undangan.

Dalam hal terlapor merupakan tim kampanye, relawan pasangan calon, anggota partai politik, orang atau badan hukum dan/atau penyelenggara pemilihan, calon/pasangan calon dapat menjadi pihak terkait dalam sidang pemeriksaan laparan dugaan pelanggaran terstruktur, sistematis, dan masif. Alat bukti dapat berupa: keterangan saksi; surat atau tulisan; petunjuk; dokumen elektronik; keterangan pelapar atau keterangan terlapor dalam sidang pemeriksaan; dan/atau keterangan ahli. 
Alat bukti keterangan saksi merupakan keterangan yang diberikan oleh seseorang yang melihat, mendengar secara langsung dan/atau mengalami terjadinya peristiwa pelanggaran terstruktur, sistematis, dan masif. Alat bukti surat atau tulisan serdiri atas dokumen hasil pengawasan Pengawas Pemilihan dan/atau dokumen tertulis lainnya, yang tidak terbatas pada akta saja. Alat bukti ini dituangkan dalam bentuk salinan yang dibubuhi materai secukupnya pada setiap dokumen sesuai dengan ketentuan peraturan perundangundangan. Alat bukti dapat ditunjukkan dan dilampirkan dalam bentuk salinan oleh Pengawas Pemilihan dalam pemeriksaan atas permintaan majelis pemeriksa. Alat bukti petunjuk merupakan perbuatan, kejadian atau keadaan, yang karena persesuaiannya, baik antara yang satu dengan yang lain, maupun dengan pelanggaran itu sendiri, menandakan bahwa telah terjadi suatu pelanggaran terstruktur, sistematis, dan masif.

Alat bukti dokumen elektronik merupakan setiap informasi elektronik yang dibuat, diteruskan, dikirimkan, diterima, atau disimpan dalam bentuk analog, digital, elektramagnetik, optikal, atau sejenisnya, yang dapat dilihat, ditampilkan, dan/atau didengar melalui komputer atau sistem elektronik, termasuk tetapi tidak terbatas pada tulisan, suara, gambar, peta, rancangan, foto atau sejenisnya, huruf, tanda, angka, kode akses, simbol atau perforasi yang memiliki makna atau arti atau dapat dipahami oleh orang yang mampu memahaminya.

Alat bukti keterangan pelapor atau terlapor merupakan keterangan pelapor atau terlapor yang disampaikan secara langsung atau melalui kuasanya dalam sidang pemeriksaan laporan dugaan pelanggaran administrasi. Alat bukti keterangan ahli merupakan keterangan yang disampaikan pada pemeriksaan oleh seseorang sesuai dengan kompetensi dan keahliannya.

Barang bukti merupakan barang atau benda bergerak yang seluruhnya atau sebagian diperoleh, dan/atau telah dipergunakan sebagai alat, dan/atau yang berkaitan dengan peristiwa pelanggaran administrasi yang diperlukan dalam pemeriksaan di Bawaslu atau Bawaslu Provinsi guna menunjang alat bukti, memperjelas, dan membuktikan suatu peristiwa pelanggaran administrasi.

Dari uraian di atas dapat diketahui bahwa pelanggaran administrasi bukan hal yang sepele sehingga perlu diperhatikan secara sungguh-sungguh juga. Dalam hal ini peranan Ilmu Administrasi sangat penting terutama menyangkut alat bukti dan barang bukti berupa dokumen-dokumen administrasi.

Pada dasarnya, kebijakan publik umumnya harus dilegalisasikan dalam bentuk hukum, pada dasarnya sebuah hukum adalah hasil dari kebijakan publik. ${ }^{9}$ Kebijakan publik yang dilakukan petahana selama menjabat, menjadi salah satu ukuran yang menentukan kemenangannya dalam pilkada. ${ }^{10}$ Oleh karena itu, kebijakan publik sering dianggap sebagai kampanye dari petahana yang mencalankan lagi pada periode kedua. Dalam hal ini kebijakan publik itu dapat juga menjadi alasan bagi pemilih unruk tidak memilih karena menganggap kebijakan publik yang diambil petahana tidak sesuai.

Dalam beberapa Pemilihan Gubernur dan Wakil Gubernur, Bupati dan Wakil Bupati, serta Walikata dan Wakil Walikata beberapa arang gagal dikarenakan tidak memenuhi syarat administrasi seperti ijazah. Padahal mereka tentu sudah melalui tahap penyaringan di parpai politik. Dleh karena itu, partai politik pengusung

\footnotetext{
${ }_{9}^{9}$ Muchsan dan Fadilah Putra, Hukum dan Kebajakan Publik, Malang: Universitas Sunan Giri Surabaya bekerja sama dengan Averraes Press, 2015, hal.37.

IDSuyatno, Pemilihan Kepala Daerah (Pilkada) dan Tantangan Demokrasi Lokal di Indonesia, Politik Indonesia: Indanesian Political Science Review I (2) (2016), hal. 226.
} 
sebelum mendaftarkan calannya ke KPU harus telah menemukan pasangan calon yang kapabel dan akuntabel disamping tingkat elektabilitas memadai."

Selama ini perhatian masyarakat lebih tertuju kepada pelaksana dan peserta padahal banyak pihak yang terlibat dalamm Pemilu. Bagi pihak-pihak lain di luar penyelenggara pemilu maupun pemilukada yang terbukti melakukan pelanggaran perlu diterapkan sanksi yang tegas sehingga diharapkan mampu memberikan efek jera bagi para pelakunya maupun pihak-pihak yang ingin melakukan pelanggaran serupa. ${ }^{12}$

Dari perspektif demokrasi, sebenarnya Pemilukada sangat baik secara substantif bagi perkembangan demokrasi, Akan tetapi, realitas umum mengatakan bahwa Pemilukada belum mampu menjamin terwujudnya demokrasi bahkan cenderung mendistarsi demokrasi. Terbukti dalam implementasinya, Pemilukada menghasilkan berbagai persaalan yang justru cenderung mencederai demakrasi. ${ }^{3.3}$ Salah satu upaya yang strategis dalam memperbaiki penyelenggaraan pilkada adalah dengan melakukan penguatan fungsi

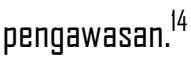

Proses demokrasi yang sedang berjalan masih banyak dipandang sebatas tatanan aturan dan mekanisme semata, tetapi belum sepenuhnya mewujudkan pemerintahan yang benar-benar aspiratif dan membuka ruang partisipasi rakyat secara luas. Oleh karena itu, demokrasi yang telah berhasil diwujudkan itu sering disebut sekadar demakrasi mekanis, belum mencapai demokrasi substantif. ${ }^{15}$

Dalam hasil kajian yang dilakukan oleh para ilmuwan di bidang Administrasi Publik, menurut Wempy Banga perlu dijadikan sebagai suatu tantangan yang harus diatasi dalam rangka mewujudkan tatanan Administrasi Publik kontemparer di masa depan antara lain sistem rekruitmen bakal calon dan calon Presiden/Wakik Presiden, Anggata DPR pusat, termasuk bakal calon dan calon Gubernur/Wakil Gubernur, Bupati/Walikata dan Wakil Bupati/Wakil Walikata, dan DPRD Provinsi/Kabupaten/Kota perlu diatur dalam regulasi yang terkait agar sejak awal dilakukan seleksi oleh lembaga independen yang difarmalkan. ${ }^{16}$

Dalam mencari format sistem pilkada langsung tampaknya tidak sekali jadi. Uل tentang Pemilihan Kepala Daerah kerap mengalami bongkar pasang dengan melakukan beberapa kali revisi. Bahkan, karena pilkada secara langsung dianggap telah terjadi maney politics dan banyak kepala daerah yang menjadi tersangka, ada keinginan kuat agar Pemilihan Kepala Daerah dikembalikan kepada DPRD. Tentu saja rakyat menolak keinginan mengembalikan Pemilihan Kepala Daerah kepada DPRD tersebut. ${ }^{17}$

\section{KESIMPULAN}

Berdasarkan uraian yang telah disampaikan dapat diketahui bahwa dalam Pemilihan Gubernur dan Wakil Gubernur, Bupati dan Wakil Bupati, serta Walikata dan Wakil Walikata Tahun 2020 ditemukan juga

\footnotetext{
"Affan Sulaeman, Demokrasi, Partai Politik, dan Pemilihan Kepala Daerah, CosmoGav, Vol.I No.I, April 2015, hal.23.

12 Tarma Sartima, "Menyoal Kode Etik Penyelenggara ataukah Penyelenggaraan Pemilu?", dalam Anna Erliyana (penyunting), Prablematika Pemilukada Serentak 20I6, Jakarta: Dewan Kehormatan Penyelenggara Pemilu (DKPP), 20I6, hal. 255.

${ }^{13}$ Konpress, Demokrasi Lokal: Evaluasi Pemilukada di Indanesia, Jakarta: Konstitusi Press, 2012

${ }^{14}$ Marzuki Lubis, "Mewujudkan Pemilihan Kepala Daerah Serentak yang Berkualitas melalui Pengiatan Fungsi Pengawasan", dalam Eka N.A.M Sihombing ¿ Ali Marwan Hsb, Paradigma Hukum Ketatanegaraan Indanesia, Dalam Rangka Hari Llang Tahun Ke-SD Praf.Dr.M Sally Lubis,S.H., Medan: Enam Media, 2020, hal.939.

15. Janedjri M Gaffar, Demakrasi Kanstitusional, Praktik Ketatanegaraan Indonesia Setelah Perubahan UUD 1945, Jakarta: Konstitusi Press, 20I2, hal.43.

${ }^{16}$ Wempy Banga, Kajian Administrasi Publik Komtemporer, Konsep, Tecri, dan Aplikasi, Yogyakarta: Gaya Media, 20I8, hal.175.

17 Lili Ramli, Pilkada Langsung, Calon Tunggal, dan Masa Depan Demokrasi Lokal Direct Local Election, Single Candidate and The Future of Local Demacracy, durnal Penelitian Palitik, Vol. 15, №. 2, Desember 2018, hal. 158.
} 
pelanggaran administrasi. Dalam penyelesaian pelanggaran administrasi maka peran ilmu administrasi sangat penting terutama dalam hal alat bukti dan barang bukti. Oleh karena itu, para pelaksana pemilihan perlu dilengkapi dengan kemampuan administrasi agar dapat mencegah dan menyelesaikan pelanggaran dengan tepat.

\section{DAFTAR PUSTAKA}

Banga, Wempy, 2018., Kajian Administrasi Publik Kantemporer, knnsep, Teari, dan Aplikasi, Yogyakarta: Gaya Media.

Dhesinta, Wafia Silvi, 2016., Calan Tunggal Dalam Pemilihan Umum Kepala Daerah dan Kansep Demakrasi (Analisis Terhadap Pemilihan Kepala Daerah Kabupaten Blitar Tahun 2015), Jurnal Cita Hukum. Vol. 4 No. I Juni 20I6. P-ISSN: 2356-1440. E-ISSN: 2502-230X.

Gaffar, Janedjri M. 20IZ., Demakrasi Kanstitusional, Praktik Ketatanegaraan Indanesia Setelah Perubahan UUD 1945, Jakarta: Konstitusi Press.

Huda, Ni'matul, 2005., Dtonami Daerah. Filasafi. Sejarah Perkembangannya, dan Prablematika, Pustaka Pelajar, Yogyakarta,

Konpress. 201Z., Demakrasi Lokal: Evaluasi Pemilukada di Indanesia, Jakarta: Konstitusi Press.

Lubis, M Solly Lubis, 2014., Politik Hukum dan Kebijakan Publik (Legal Policy and Public Policy), Bandung: Mandar Maju.

Lubis, Marzuk. 2020., "Mewujudkan Pemilihan Kepala Daerah Serentak yang Berkualitas mela/ui Pengiatan Fungsi Pengawasan", dalam Eka N.A.M Sihombing \& Ali Marwan Hsb, Paradigma Hukum Ketatanegaraan

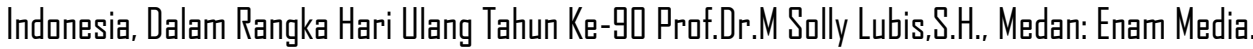

Mana, Bagir. 2004., Perkembangan ULD 1945, Yogyakarta: FH UلII Press.

Muchsan \& Fadilah Putra, 2005., Hukum dan Kebajakan Publik, Malang: Universitas Sunan Giri Surabaya bekerja sama dengan Averroes Press,

Munte, Herdi Munte. 2020., Pengantar Pelanggaran dan Sengketa Hukum Pemilukada (Teari dan Praktek), Medan: Enam Media

Pardede, Marulak. 2018., Legitimasi Pemilihan Kepala/Wakil Kepala Daerah Dalam Sistem Pemerintahan Dtanumi Daerah (Legitimacy of Regiana/ Head/Deputy Head Election in The Regiana/ Autonomous Administration System), Jurnal Penelitian Hukum DE JURE, ISSN 14ID-5632 Vol. I8 №. 2, Juni 2018.

Romli, Lili Romli. 2018., Pilkada langsung, calon tunggal, dan masa depan demakrasi lokal direct lacal election, single candidate and the future of laca/ demacracy, Jurnal Penelitian Politik, Val. 15, №. 2, Desember 2018.

Sarlima, Tarma Sartima, 2016., "Menyaal Kade Etik Penyelenggara ataukah Penyelenggaraan Pemilu?", dalam Anna Erliyana (penyunting), Prablematika Pemilukada Serentak 2DIG, Jakarta: Dewan Kehormatan Penyelenggara Pemilu (DKP)).

Sulaeman, Affan. 2015., Demakrasi, Partai Palitik, dan Pemilihan Kepala Daerah, CasmaGav, Vol.I No.I, April Z0I5. Suyatno, 20I6., Pemilihan Kepala Daerah (Pilkada) dan Tantangan Demakrasi Lokal di Indanesia, Politik Indanesia: Indonesian Political Science Review I (2) (2016).

\section{Peraturan Perundang-undangan}


Undang-Undang Dasar Negara Republik Indanesia Tahun I945 .

Undang-Undang Nomar 7 Tahun 2017 tentang Pemilihan Umum.

Undang-Undang Nomor I Tahun 2015 tentang Penetapan Peraturan Pemerintah Pengganti Undang-Undang Nomor I Tahun 2014 tentang Pemilihan Gubernur, Bupati, dan Walikota jo Undang-Undang Nomor 8 Tahun 2015 tentang Perubahan Undang-Undang Nomar I Tahun 2015 jo Undang-Undang Nomar I0 Tahun 2016 tentang Perubahan Kedua Undang-Undang Nomar I Tahun 2015 jo Peraturan Pemerintah Pengganti UndangUndang Nomar 2 Tahun 2020 tentang Perubahan Ketiga Undang-Undang Nomor I Tahun 2015.

Peraturan Mahkamah Konstitusi Nomor 5 Tahun 2017 tentang Pedoman Beracara dalam Perkara Perselisihan Hasil Pemilihan Gubernur, Bupati, dan Waliknta.

Peraturan Mahkamah Konstitusi Nomor G Tahun 2017 tentang Pedoman Beracara dalam Perkara Perselisihan Hasil Pemilihan Gubernur, Bupati, dan Walikota dengan satu pasangan calon.

Peraturan Bersama Badan Pengawas Pemilihan Umum, Kepala Kepolisian Republik Indonesia, Kejaksaan Agung Nomar 5 Tahun 2020 tentang Sentra Penegakan Hukum Terpadu pada Pemilihan Gubernur dan Wakil Gubernur, Bupati dan Wakil Bupati, Walikota dan Wakil Walikata (Sentra GAKKLMDU).

Peraturan Dewan Kehormatan Penyelenggara Pemilihan Umum Republik Indonesia Nomar 2 Tahun 2017 tentang Kade Etik dan Pedoman Perilaku Penyelenggara Pemilihan Umum.

Peraturan Badan Pengawas Pemilihan Umum (BAWASLU) Nomor 13 tahun 2017 tentang Tata Cara Penanganan Pelanggaran Administrasi Terkait Larangan Memberikan dan/atau Menjanjikan Lang atau Materi Lainnya Yang Dilakukan Secara Terstruktur, Sistematis, dan Masif Dalam Pemilihan Gubernur, Bupati, dan Walikota. 